\section{Despairing demand for more}

THE Oliver Twist of British civil science, the Advisory Board for the Research Councils (ABRC), has this year asked for more in even stronger language. The preface to the annual claim for research funds, agreed by the board at its meeting at the end of April and now on its way to Sir Keith Joseph, the Secretary of State for Education and Science, says that "Parliament, the government and the country as a whole" are "complacent" about the present condition of the dual support system, the means by which support for university research is channelled through the research council and the University Grants Committee.

ABRC says that this complacency is born of a misconception of the function of the research councils and of basic research as such. The board thinks it necessary to point out that it is not true to say that the research councils support only research for its own sake and that academic research is remote from the real world.

As in previous annual applications for funds, ABRC acknowledges that there are limits to what can be afforded for basic research. But it insists that the government which ultimately foots the bill cannot expect that new technologies will emerge unless there is basic science from which they can spring. The board's application also argues that the pace of scientific advance is now such that copying other innovative technology is no longer a recipe for industrial success.

Part of the board's difficulty, this year as previously, is that the government appears on the face of things to have kept the Prime Minister's promise in 1980 that the research budget would be "protected". Using the retail price index as a measure of inflation, the science budget has in fact increased by 6.4 per cent since 1981-82. Even allowing for the decline of the research councils' other income, mostly by way of research commissions from government departments, amounting to roughly 7 per cent on a sixth of the total science budget during the same period, the total income of the research councils has increased by roughly four per cent.

The board says that this simple arithmetic is misleading partly because the retail price index is not a good measure of the increased cost of research. Rather, the board calculates that the real volume of research supported with the funds within its purview has declined by 5 per cent over four years. Matters have been made worse, the argument continues, by the 8 per cent reduction (in real terms) of the budget of the University Grants Committee.

The case is sustained by a harrowing account of the changes which have been brought about within the research council system in the past few years. The total staff of the five research councils has declined

\section{UK neuroscience}

by a fifth, by 2,000 . But in general, ABRC says, the councils have found that the rate at which they are able to fire or redeploy staff is itself constrained by their shrinking budgets.

The consequences of this state of affairs are catalogued in detail. Thus, the submission to the government is believed to say, the Science and Engineering Research Council is no longer able to make full use of new facilities because it cannot afford the research equipment, is having to pass up opportunities for international collaboration for lack of funds, is unable to meet its commitments (to other government agencies) to encourage information technology and cannot give adequate support to several named areas of research of vital industrial promise.

Other lost opportunities cited by ABRC include the Medical Research Council's incapacity to provide more than half the equipment needed for a new programme of research in protein engineering at the Laboratory of Molecular Laboratory at Cambridge, the Natural Environment Research Council's incapacity to participate in the new ocean drilling programme and the incapacity of the Agricultural and Food Research Council to afford more than a third of the cost of replacing outdated research equipment.

By comparison with previous submissions, the latest request for more research money is terse, almost despairing, as if it had been judged imprudent that an unwilling government should be confused with a plethora of facts. ABRC will protest separately about the way in which the budget of the Agricultural and Food Research Council has been cut by $£ 5$ million this year and by twice as much in succeeding years because of a Treasury edict. Meanwhile, ABRC's modest request of government is $£ 15$ million for the year beginning next April, twice as much in the succeeding year and $£ 40$ million in 1988-89.

On past form, ABRC's submission and the response to it will be published in the autumn.

\title{
New lab, old unit in new role
}

BRITISH neuroscience was given a muchneeded fillip last Friday with the inauguration of the new $£ 25$-million Merck Sharp \& Dohme Neuroscience Research Centre near Harlow, Essex, which is dedicated to investigating chemical transmission processes in the brain. The hope is that one outcome will be the development of new drugs for treating neurological and mental disorders. The centre is at present paying particular attention to senile dementia (Alzheimer's disease) and inhibitory pathways.

The centre is directed by Dr L.L. Iversen, formerly head of the Medical Research Council (MRC) Neurochemical Pharmacology Unit at Cambridge. It will eventually employ about 160 professionals and 50-60 support staff, making it one of the largest brain research centres in the world. It comprises departments of medicinal chemistry, biochemistry and pharmacology, including neurophysiology and animal behaviour, but project teams will be interdisciplinary, involving staff from various departments.

Iversen emphasizes the goal of designing drugs based on a knowledge of the structure and function of the membrane receptor sites for the appropriate transmitter chemicals, instead of the empirical synthesis of chemicals which are then screened for their effects on behaviour. The centre also includes a small clinical research unit to undertake preliminary trials of new drugs. There will be collaboration with universities, particularly under research council schemes for joint direction of research studentships, and with hospitals.

According to Merck Sharn \& Dohme. the centre has been established in Britain because of the "pathfinding leadership of British scientists in brain research". Its existence should provide much-needed encouragement to the younger generation of British neuroscientists. The grim job prospects in academic research are resulting in fewer good students going into neurosciences and many that do are leaving Britain after their training. The centre has already attracted several younger scientists back from the United States.

Meanwhile, the Neurochemical Pharmacology Unit at Cambridge, threatened with closure a year ago, has been reborn. After a controversial two-year search to replace Dr Iversen as head of the unit (see Nature 309, 486; 1984), MRC has appointed Professor E. Barnard of the Biochemistry Department, Imperial College, London, as the new director of the unit, now to be known as the Molecular Neurobiology Unit, from 1 October. In the same building as the MRC's Laboratory of Molecular Biology in Cambridge, Barnard's laboratory is intended as the focus in Britain of the use of molecular genetics techniques to study neurotransmitters.

The new unit will have two main lines of research - the development of animal models for the study of muscular dystrophy and motor neurone disease, and the cloning of brain receptors and their genes, in particular in nicotinic acetylcholine receptor and receptors for neuropeptides such as enkephalins and substance P. At full strength the unit will comprise five senior scientists and about 35 visitors, postdoctoral fellows, students and technicians.

Jennifer Altman 